\title{
Plant breeding and in situ utilization of palm trees
}

\author{
Melhoramento genético e utilização in situ de palmeiras
}

\author{
Mercedes Rivas ${ }^{\text {I }}$ Rosa Lía Barbieri" Luciano Carlos da Maia ${ }^{\text {III }}$
}

\section{- REVIEW -}

\section{ABSTRACT}

The palm tree family (Arecaceae) is constituted by approximately 3000 species mainly distributed in the tropics and subtropics. As a source of a variety of products they contribute to the world and local economies, and also to peoples lifestyles. Historically their use has been based on wild populations, but also on local domestication. Very few species are subject of plant breeding programs and are cultivated in the world. This is the case of the African oil palm (Elaeis guineensis), in which investment and development consortiums invest high sums. Another kind of crop is the date palm (Phoenix dactylifera), which was domesticated thousand of years ago and whose success is based in the export of a fine product with worldwide recognition. In this case the production is based on traditional varieties and has very incipient breeding programs. A third group of palms includes those species from which products are obtained and manufactured for local development. The objective of this literature review is to contribute in the analysis of opportunities and weaknesses to investing in domestication and plant breeding programs in those palm trees with a recognized productive value.

Key words: Arecaceae, Elaeis guineenis, Phoenix dactylifera, domestication, in situ management.

\section{RESUMO}

A família das palmeiras (Arecaceae) é constituída por aproximadamente 3000 espécies, distribuídas principalmente nos trópicos e subtrópicos. Como fonte de uma variedade de produtos, contribuem para a economia mundial e local, e também para o modo de vida de várias pessoas. Historicamente, seu uso tem sido baseado em populações silvestres, mas também em domesticações locais. Muito poucas espécies estão submetidas a programas de melhoramento genético e são cultivadas a nível mundial. Este é o caso da palmeira de dendê (Elaeis guineensis), na qual consórcios de investimento e desenvolvimento investem altas quantias de dinheiro. Outro tipo de palmeira cultivada é a tamareira (Phoenix dactylifera), a qual foi domesticada milhares de anos atrás e cujo sucesso está baseado na exportação de produtos com reconhecimento mundial. Nesse caso, a produção está baseada em variedades tradicionais e os programas de melhoramento ainda são incipientes. Um terceiro grupo de palmeiras inclui aquelas espécies cujos produtos são obtidos $e$ manufaturados para o desenvolvimento local. O objetivo desta revisão bibliográfica é contribuir para a análise de oportunidades e fragilidades no investimento em domesticação e programas de melhoramento das palmeiras com valor produtivo reconhecido.

Palavras-chave: Arecaceae, Elaeis guineenis, Phoenix dactylifera, domesticação, manejo in situ.

\section{INTRODUCTION}

It is estimated that the Palmae or Arecaceae family comprises approximately 189 genera and about 3000 species, which a classified in five sub-families with a variable number of tribes and sub-tribes (DRANSFIELD et al., 2005). They are distributed mainly in tropical and subtropical areas, although a few of them can be found at higher latitudes in the southern hemisphere. The main diversification centers are found in the equatorial coast of Africa, Oceania, the Brazilian

'Facultad de Agronomía, Universidad de la República, Montevideo, 1290, Uruguay. E-mail: mrivas@fagro.edu.uy. Autor para correspondência. IIEMBRAPA Clima temperado, Pelotas, RS, Brasil.

IIIFaculdade de Agronomia “Eliseu Maciel” (FAEM), Universidade Federal de Pelotas (UFPel), Pelotas, RS, Brasil. 
coast, the Amazon, Indonesia and the Antilles (MOORE \&UHL, 1982).

The palm trees affects significantly both the economy and the everyday of million of people around the world. Its contribution to the world economy, the local economies and the people life styles is huge. It is also surprising the huge number of products that can be obtained from these species. Among the food products can be highlighted the fruits, seeds, the 'palmito', honeys, 'sagu' (material with starch extracted from the centre of the trunks), different drinks obtained from the sap or the fruits, crystallized sugar from the sap, among others. Other kinds of products are fibers, oils and waxes. In these different ways, palm trees contribute to the food, housing, furniture, energy, clothing and gardens (JONES, 1995). Most of the palm trees are used directly in nature, under different extractivism rates which in some cases lead to genetic erosion.

The main species cultivated are the African oil palm (Elaeis guineensis), the coconut tree (Cocos nucifera), the date palm (Phoenix dactylifera) and the betel nut palm (Areca catechu) with 14.585.811, 11.208.072, 1.264.611 and 834,878 hectares respectively in 2008 (FAO, 2010).

With the objective of studying the different situations in which the palm trees are used we will present the case of the African oil palm as an example of a crop with an important investment in the development of plant breeding, machinery, agrochemicals, tissue culture, oil fractionation and oil chemistry (CORLEY \& TINKER, 2003); and more recently in molecular genetics and genetic engineering. An intermediate situation is found for the date palm, a successfully crop but with smaller economic importance. Finally we will consider the situation of species under domestication that are used by gathering.

\section{The African Oil Palm (Elaeis guineensis Jacq.)}

The genus Elaeis belongs to the subfamily Arecoideae, tribe Cocoseae and subtribe Elaeidinae, according the classification by DRANSFIELD et al. (2005). It is represented by two species, E. guineensis Jacq. and $\boldsymbol{E}$. oleifera H.B.K. Other two possible species of the genus are controversial, Elaeis odora of South America and Elaeis madagascariensis of Madagascar. The African oil palm (Elaeis guineensis) is endemic of the tropical rain forests of the central and western Africa, spreading over Angola, Cameroon, Congo, Ghana, Ivory Coast, Nigeria and Zaire. E. oleifera extends in the tropical area of America from Mexico to the Amazon (Brazil, Bolivia, Colombia and Peru) (SOH et al., 2003). Both species cross and produce fertile hybrids (BARCELOS et al., 2002).
The African oil palm is the oil crop of highest yield, with yield averages of 3-4 tons per hectare by year of mesocarp oil. This means that its productivity is several times higher than most of the oil crops. Also the African oil palm can produce an average 0.5 tons of kernels per hectare per year, which contain approximately a $47 \%$ of oil (WAHID et al., 2005). Experimental yields have reached 12tons of oil per hectare per year, so if the breach between the experimental data and the field results diminish, the African oil palm will keep on expanding it's differences in yield in relation to other oil crops as soybeans $(\mathrm{SOH}$ et al., 2003).

Most of the production is realized in Malaysia and Indonesia, with 8.900.000 hectares and a production of the $82 \%$ of the entire world volume of mesocarp oil in 2008 (FAO, 2010). Other countries that produce the crop are Nigeria, RD Congo, Ivory Coast, Ghana, Guinea, Colombia, Ecuador, Papua New Guinea, Honduras, Brazil and Cameroon, among others.

The history of the genetic improvement of these species and the main scientific and technological developments are presented here, with the objective of understanding the bases on which it has been domesticated and an industry of great importance established.

In the Asian Southeast (Indonesia and Malaysia), the genetic improvement has been based on a population of palms named 'Deli dura', which was developed with the objective of improving oil quality starting from only four palms brought by the Dutchs in 1848 to the botanical garden Buitenzorg (now Bogor) in Indonesia (WAHID et al., 2005). The fruits are of the type 'dura', which means that they present a thick endocarp, but they present some differential characteristics in relation to the 'dura' germplasm of Africa: paler fruits, of major size and with higher content of oil in the mesocarp. At the beginning of genetic improvement, crosses were made among the most productive individuals of 'Deli dura' (CORLEY \& TINKER, 2003).

In Africa, using different germplasm, the crop improvement took different directions. The palms with thin endocarp ('teneras') were used in plant breeding due their high oil content by inflorescence. When these palms were crossed their progeny showed a $25 \%$ of plants without endocarp and female sterility ('pisiferas'), which allowed to understand that this characteristic was determined by a single gene (CORLEY \& TINKER, 2003).

The most productive variety actually cultivated is of 'tenera' type with thin endocarp, generated by crosses between 'dura' germplasm and 
'pisifera' genotypes that act as pollen donors (WAHID et al., 2005). Starting from distributed progenies of the 'Deli' and its selection in different breeding programs, subpopulations were developed, of which 13 would be in use nowadays (PURBA et al., 2000). Dwarf variants have also been found, which are of interest to facilitate the tasks of crop harvest (SOH et al., 2003).

Among the genetic resources of the 'pisiferas' germplasm, the population AVROS stands out for its good vigor, precocious bearing, mesocarp thickness and high oil production. In countries such as Colombia, Costa Rica, Indonesia, Malaysia and Papua New Guinea, the production of commercial hybrid seed is based on crosses of "Deli dura" by the 'pisiferas' lineage of AVROS (SOH et al., 2003).

The 'La Me' population of teneras (Ivory Coast) is characterized for being constituted by small palms with smaller inflorescences and small fruits, but with valuable characteristics of adaptation to suboptimal growing conditions. Also there are other materials of interest of the type 'tenera' that stand out like the populations Yangambi (Congo), Binga, Ekona and Calabar (SOH et al., 2003).

In spite of the apparent diversity of the developed materials, most of the production of hybrid seed is still based on materials 'Deli' and the populations Yangambi/AVROS and La Me, which derive from very few wild palms. According to COCHARD et al. (2009) at the breeding programs the work is based on 4 'Deli' materials, 3 La Mé and approximately 10 of Congo, although one of them represents more than the $50 \%$ of this last origin.

It is due to the concern of a narrow genetic base on which the crop is being developed, that in the 80s started the first field collections expeditions in the area of wild distribution.

The studies of PURBA et al. (2000); MAIZURA et al. (2006) and COCHARD et al. (2009), that analyzed the genetic diversity of collections of African oil palm by AFLPs, RFLPs and microsatellites respectively, found that the 'Deli' germplasm constitute a differentiated group with scarce genetic diversity. MAIZURA et al. (2006) estimates a loss of 36 alleles in the Deli dura in relation to natural populations; and HAYATI et al. (2004) found that the population 'Deli' did not present rare alleles or intermediate genetic frequencies.

According to COCHARD et al. (2009), the populations Deli of Indonesia had the lower heterozigosity $\left(\mathrm{H}_{0}=0.362\right)$ and the biggest inbreeding coefficient $\left(\mathrm{F}_{\mathrm{IS}}=0.2953\right)$. In particular, the two origins Dumpy and Sungei Pancur presented the lower heterozigosity, of 0.0893 and 0.1429 , respectively. This is explained by its development after four to five generations of mass selection in a context of inbreeding of scarce original materials.

In relation to the countries and regions of higher diversity, MAIZURA et al. (2006) found that the populations of Nigeria presented the higher average number of alleles per loci and the higher percentage of polymorphic loci, coinciding with the results of HAYATI et al. (2002) that found the higher diversity in Cameroon and Nigeria. It is proposed that Nigeria is the center of diversity of African oil palm, which is also sustained in the fact that as the geographical distance increases, the indexes of diversity decrease.

COCHARD et al. (2009) distinguished three groups of germplasm, the group I integrated by the germplasm of Ivory Coast, the group II integrated by the germplasm of the countries 'Benin-NigeriaCameroon-Congo-Angola', and the group III integrated by the Deli materials. The allelic distribution in the three groups indicated that the group I show specific alleles that do not appear in the group II and vice versa. The dissimilarity of materials of Ivory Coast would be explained by the discontinuity in the distribution of African oil palm bypassing the Dahomey Gap. On the other hand, all the alleles present in the Deli origin were found in the II group, whereas only $43.4 \%$ of the same alleles were found in the group I.

The identification of two groups, the Congolese one and the one from Guinea, reflects the evolutionary history of the species; whereas the Deli group is only a derivative of the Congolese group. This information is considered very interesting by COCHARD et al. (2009), who proposes the realization of new crosses, the improvement of the Congolese group by means of crossings with Deli, which already has an important genetic progress, and then to cross with materials of the group I to achieve higher levels of heterosis. The need to maintain separate populations of 'dura' and 'pisifera' has led to the adoption of breeding schemes similar those used in corn breeding and for animal genetic improvement.

According to SOH et al. (2003), the plant breeding targets can be classified in four groups: yield potential, adaptation, oil quality and stress tolerance. In case of yield no ideotype has been defined and selection is not done for physiological characteristics. Nevertheless indirect selection for characteristics that facilitate crop harvest are carried out, like for low height plants, long inflorescences and longer maintenance of mature fruits in the tree.

For adaptation, the matter is the increasing of yield potential for sites with soil and moisture restrictions, among other limiting factors. Anyhow, it 
is necessary to point out that the genotypeenvironment interaction has been very little considered, and needs to be a priority topic of work.

Oil quality is the main target of $\boldsymbol{E}$. guineensis genetic breeding, especially for its introduction to the cooking market in temperate weather countries. The percentage of saturated fatty acids is high, which generates two problems, its solidification at lower temperatures and the relation done with the oil of Cocos nucifera wich is undesirable for the human health. The above mentioned happens even though the oil of African oil palm presents approximately $50 \%$ of unsaturated fatty acids and that among the saturated ones predominates the palmitic acid that may have a neutral behavior as cholesterolemic. So the target is to achieve more liquid oil and to fulfill the conditions of the American Heart Association: not to consume more than a $30 \%$ of daily fats, a third of saturated (lauric, myristic, palmitic and stearic fatty acids), a third of polyunsaturated (linoleic) and a third of monounsaturated (oleic). Plant breeding seeks to reduce the saturated fatty acids and to increase the polyunsaturated ones (CORLEY \& TINKER, 2003).

On the other hand, the oil of $\boldsymbol{E}$. guineensis contains antioxidants as carotenoids, tocoferols and tocotrienols, the contents of which are targets of increase by genetic breeding.

Breeding for biotic stress tolerance (diseases and pests) is considered the priority in the Asian Southeast, searching for resistance to Ganoderma boninense. The absence of efficient screening method is an important limiting factor in this case. Other important disease is caused by Fusarium oxysporum $f$. sp. elaedis, particularly in Western Africa. A physiological disease occurs in palms from two to three years old, which causes important losses. This disease is due to a recessive gene, whose expression is masked by an epistatic gene that confers an incomplete penetrance to it. The breeding in this case consists in elimination of families with any susceptible progeny. The priorities for tolerance to abiotic stresses are resistance to drought and tolerance to magnesium deficiency. Breeding for cold tolerance is also starting (SOH et al., 2003).

Elaeis guineensis is allogamous and monoecious. Directed crosses are done according to a protocol that involves the isolation of inflorescences few days before the feminine ones are receptive and that the masculine ones are in anthesis. The pollen can be stored in a freezer, after being dried in a stove. The pollination is done introducing pollen mixed with talc through a perforation in the bag that contains the feminine inflorescence. The bag is removed after six months and the fruits are harvested approximately five months later (SOH et al., 2003).

The method of modified recurrent selection involves in the first instance selection of pisiferas (teneras) based on the performance of their progenies. Then they are proved in crosses with a sample of chosen "deli” palms (top-cross). Selected pisiferas are those of higher general combinatorial aptitude (GCA) and are those which are crossed with the phenotipically chosen "deli" to form the tenera hybrids. Selected parents in each cycle are crossed between themselves, as a way of continuing the breeding of the base population (CORLEY \& TINKER, 2003).

In case of recurrent reciprocal selection both the GCA and the GCE (specific combinatorial aptitude) are exploited, which increases the possibilities of obtaining hybrids with higher heterosis. For this breeding method programs of big size are needed, because to produce three to four million hybrid seeds, select the top $15 \%$ of the crosses, evaluate 500 crossings and 180 self-fertilizations requires an area of 600 hectares and 15 to 25 years (SOH et al., 2003).

Due to these difficulties, the cycle length and the required areas for trials, to know the genetic values of the parents is very useful to predict the value of the hybrids, although one of the frequent problems is the amount of unbalanced information. PURBA et al. (2001), with a series of unbalanced data and pedigree information from a breeding program, found that the use of the BLUP (best linear unbiased predictor) method to estimate the breeding value of the hybrids can be very usefull. The high correlation between the observed values and the expected performance of the hybrids, using an additive model, is considered to be enough to select for oil production. From the practical point of view these results can significantly contribute to improve the efficiency of reciprocal recurrent selection programs.

Nonetheless, in spite of the limiting factors presented by breeding programs, the yield increases obtained in the last 50 years are assumed to be $70 \%$ due to the conventional genetic breeding and $30 \%$ due to better agronomic practices (SOH et al., 2003).

The construction of a high density linkage map of a cross between 'delzi' x 'tenera', with 255 microsatellites, 688 AFLPs and the Sh locus (the gene that controls the presence or absence of the endocarp), distributed over 16 linkage groups (a linkage group for every homologous chromosome), constitutes a valuable step towards the identification of QTLs (Quantitative trait loci) and the possibility of realizing marker assisted selection (BILLOTTE et al., 2005). 
Other breeding methods involve the achievement of intra-specific backcrosses and interspecific crosses with Elaeis oleifera. The characteristics of interest that presents American oil palm are the low rate of height growth, the high unsaturated oil and the resistance to diseases such as Fusarium (WAHID et al., 2005). Because the backcrossing programs with American oil palm need a high number of generations, SOH et al. (2003) question its use and support the improvement of the oil quality through for biological and chemical procedures at the industrial stage.

Nevertheless, as the African oil palm collections are evaluated, diversity has been found for oleic fatty acid and carotenes. This fact has allowed obtaining materials with more than $48 \%$ of oleic fatty acids (ISA et al., 2006) and others with more than 2000ppm of carotene (MOHD DIN et al., 2006). For the materials with high carotene level, since they present very low yield levels, it's been proposed the development of specialized crop for production of carotenes for the nutritive and pharmaceutical market. The materials with higher percentage of oleic acid would allow to gain access to the markets in temperate weather countries, which would allow increase an estimated $10 \%$ in palm oil exports.

From the point of view of commercial multiplication, in vitro culture occupies an important place. Although the first successes were achieved in 70 s, it wasn't until the 90s that with a great investment and the work of twenty laboratories in different countries, it was achieved the installation of crop areas from in vitro plants. Nevertheless, there are a series of unsolved problems, like somaclonal variation, the cloning efficiency and the practicality of re-cloning, among others (SOH et al., 2003).

The occurrence of plants with abnormal flowers and fruits is relatively frequent (5\%), in particular the «mantle» variant that provokes fruits abortion. Work has been done on the hypothesis of physiological, genetic and epigenetic origin of this somaclonal variant. The DNA hypometilation in the aberrant plants seems to be the principal cause of this malformation (JALIGOT et al., 2000; KUBIS et al., 2003). Now, the work proposal is to generate a diagnosis method for the 'mantle' plants, which would allow to make the in vitro culture viable in the species ( $\mathrm{SOH}$ et al., 2003).

The analysis and functional annotation of ESTs (expressed sequence tags), that allows not only comparative genetic studies, but also the development of useful markers for genetic improvement (HO et al., 2007), is one of the most recent advances. In particular the work of these authors has allowed the identification of homologue genes involved in floral development, a tool that would offer opportunities to explore the epigenetic causes of the abnormal flowering in African oil palm.

In relation to the use of genetic engineering, the first initiative had the target producing oil palms with high oleic fatty acids. More recently the target is producing oil palms with high stearic fatty acids, nutraceutic oils and biopolymers (WAHID et al., 2005). MAYES et al. (2008) points out that since 1993, when the first case of transgenic expression in oil palm tissue was reported, a significant progress has been realized in genes and promoters, in the regeneration of plants from the tissue culture and the technique of biolistic. The development of the Agrobacterium mediated transformation is one of the high priorities for the research, since it grants a higher stability to the expression of the transgenic construct. There are not transgenics of African oil palm in the market today, although research is active. Some aspects referred to biosafety and public acceptance are still to be solved (WAHID et al., 2005).

Finally, the use of African oil palm for biodiesel production is among the priorities for the next years (NASS et al., 2007).

\section{The Date Palm (Phoenix dactylifera L.)}

The date palm, subfamily Coryphoideae, tribe Phoeniceae (DRANSFIELD et al., 2005), is one of earliest domesticated fruit trees. Records of its culture exist since 4000BC in the low Mesopotamia (JONES, 1995); whereas the most ancient records of wild plants date back to 5000-6000BC in Iran, Egypt and Pakistan (EL HADRAMI \& EL HADRAMI, 2009).

The 2008 production of dates was estimated in 7.048.089 tons, principally produced in Algeria, Saudi Arabia, Egypt, the Arab Emirates, Iraq, Iran, Morocco, Oman, Pakistan and Tunis (FAO, 2010); although it is also cultivated in other countries of the world such as Spain and the United States (Arizona and California).

In addition to its commercial value, the date palm constitutes a valuable nutritive and economic resource for the people living in oases, since it is the principal vegetable resource of arid and desert areas, where it also generates a favorable microclimate for the culture of other fruit trees and vegetables (RHOUMA et al., 2008).

The dates can be consumed as fresh fruits, although the industry of dry fruits industry is its principal destination. Production is destined for a select export market, based on the quality of the product. The most popular and valued variety is 'Majhool' originated 
from Morocco; whereas the most important export volumes are constituted by the variety 'Deglet Nour' of Algeria and Tunis (EL HADRAMI \& EL HADRAMI, 2009).

The production is based on the use of traditional varieties (ELHOUMAIZI et al., 2002), although they are referred as cultivated varieties in some publications. The genetic pool is wide, of the order of 250 varieties according to RHOUMA et al. (2008) and in the order of 5000 according to EL HADRAMI \& EL HADRAMI (2009). The studies on phenotypic diversity are partial, as indicated by ELHOUMAIZI et al. (2002), who performed a morphometric analysis of vegetative characteristics in 26 varieties, whose results indicated the existence of an important diversity. The analyses of genetic diversity by RAPDs (SEDRA et al., 1998), microsatellites (ELSHIBLI and KORPELAINEN, 2008) and RAMPOs (RHOUMA et al., 2008) confirm a high diversity among the varieties.

Since this is a dioecious species, the varieties are constituted by pistilated plants, which are pollinated naturally by the wind, or by artificial crossings commonly realized to assure good yields. It is necessary to bear in mind that in this specie happens the phenomenon of metaxenia, by which the pollen has a direct influence in the size, form and color of seed and fruit; as well as in the speed of fruit development and in its moment of maturation (SWINGLE, 1928).

The varieties are usually multiplied through seeds or from shoots from the base stem. The sexual reproduction generates diverse descents with the disadvantage of not being able to identify up to the first flowering if it is feminine or masculine plant, neither to determine the value of its fruits. The vegetative reproduction has the advantage of a reduction in a period of two to three years to first flowering, although it is relatively inefficient and costly because the number of propagules per plant is relatively low (20 to 30) and they can only be used while the mother palm tree is young (10 to 15 years) (EL HADRAMI \& EL HADRAMI, 2009). Considering this limiting factor, the in vitro culture has gained importance, and in some countries it has completely or partially replaced the vegetative reproduction. This reality has generated that of some varieties exist only a dozen plants, whereas of others like 'Deglet Nour' millions of plants exist; which is provoking the increase of the monoculture, the loss of diversity and the increase of genetic vulnerability to pests and diseases (RHOUMA et al., 2008).

The main short term challenges for genetic breeding consist in maintaining genetic diversity, providing plants to forests of palms in oases. In the medium term the biggest challenge is to improve the resistance to pests and diseases and also to abiotic stresses. The main disease is caused by Fusarium oxysporum f. sp. albedinis, which already has 12 million destroyed plants, especially in Morocco and Algeria. Control mechanisms are not known for this disease and the scarce varieties that present resistance have bad date quality. Another disease has recently appeared, called 'of the fragile leaf', that has destroyed 40000 trees, but the causal organism is not known (EL HADRAMI \& EL HADRAMI, 2009).

Facing these challenges, EL HADRAMI \& EL HADRAMI (2009) state that 'very little has been done', partly due to slow growth rate and the dioic character of the species.

Some incipient programs exist in Morocco, which have selected wild palms with better resistance to Fusarium or good fruit quality, with which a crossing plan was begun, and the $\mathrm{F}_{1}$ plants are being multiplied in greenhouses and in in vitro for his later evaluation. It is estimated that it will take approximately 30 years for the creation and regeneration of the $\mathrm{F}_{1}, \mathrm{~F}_{2}$ and backcross population, which somehow justifies the scarce results obtained to the date (EL HADRAMI \& EL HADRAMI, 2009).

This experience is illustrative of problems that can arise when a crop increases its area of production based on homogeneous varieties, leaving aside the diverse local varieties that have been in use for thousands of years. The absence of breeding programs that continuously provide diverse germplasm constitutes an important risk, and the costs of breeding programs must be taken into account when expanding the monoculture.

Viability of domestication and breeding for new species of palm trees

There are probably dozens or hundreds species of palm trees that present valuable productive characteristic, a situation that could initially justify programs with objective of domestication and plant breeding for these species. Most of these species are used by local communities in their natural environment and in some cases activities of domestication have been carried out at the local level.

CLEMENT et al. (2005) raise the successes and failures of research projects targeted to the development of tropical palm trees in Brazil. In the palm trees with oil production potential, Acrocomia aculeata, Bactris gasipaes, Attalea speciosa, Oenocarpus batana and Elaeis oleifera, they emphasizes some biological limits such as their seasonal nature, their chub irregular maturation and the fast 
growth rate attained by the palm trees. The author supports that in the prospection and collection activities there must be a better prioritization of the type of plants collected to improve material selection efficiency. On the other hand, the oil extraction technique plus the installation cost of the factories has proven limiting, especially facing competition with the African oil palm and the coconut palm, which already have a solid market in a globalized world. The authors also raise the need to obtain projects with a minimal duration of ten years, that would allows to effectively attend breeding programs in perennial species, thinking the integral use of plants and the attention to the production chain. It is indicated as successful the Elaeis oleifera breeding program, which was started in the 70s has had continuity by means of the production of hybrids with $\boldsymbol{E}$. guineensis, since they produce less saturated oil, grow more slowly and present disease resistance.

For food species, CLEMENT et al. (2005) indicate that the success achieved with 'vinho de açai', produced starting from fruits of Euterpe oleracea and E. precatoria are owed basically to private enterprises. The same situation occurred with Astrocaryum vulgare and $\boldsymbol{A}$. tucuma, in which the increase of local demand has happened without the intervention of the 'Research and Development' system. The popularization of traditional foods has been the principal cause for adoption of these products, as well as some development projects.

Nevertheless, also defeats have been present as in the sweet palm heart (pupunha) in the North of Brazil, in which in spite of the true advantages that grants the fact that the species is multiple stem (caespitose) and the early production start; the agribusiness failed, basically due to not taking into account the transportation costs to the main consumption center. Finally, in the cosmetics sector, the oils of palm trees are of interest for new product development, although the specific demands are not sufficiently clear (CLEMENT et al. 2005).

In other species, such as Euterpe edulis, has emerged the idea that the management of populations in the ecosystem is the most reasonable alternative of use. The sustainable resource handling over time implies that the population dynamics should allow the restoration of individuals that are harvested. In this sense, demography, genetic diversity and reproductive biology has been researched, among other topics, in a way of being able to propose of controlled exploitation of palm heart (REIS et al., 2000). On the other hand, the farmers have not proved to be interested in this crop, especially due to ecological requirements of the species that needs shade in it early stages and its relatively low yield (REIS et al., 2008).

In case of Butia capitata, species in which the fruits are basically used for the handcraft production of liquors, jams, sweets, sauces, ice creams, yogurts, etc., the crop harvest is carried out directly from nature, both in Uruguay and Brazil. The main challenges for the in situ management consist in the development of alternatives for the conservation integrated with the local development based en commercialization of high quality products (RIVAS, 2005).

\section{CONCLUSION}

For a 'new' species to be a crop it is required its adoption by farmers, the availability of suitable 'sowing' material, with a good agronomic behavior, and that commercialization and profitability are insured. The long term continuity of plant breeding programs and associated researches must be in concordance with the future crop profitability. On the other hand, market niches and production chains must be studied in depth, as a way of avoiding wrong decisions about the crop possibilities.

In the context of globalization, the implantation of a new crop on a global scale is an enormous and expensive challenge, which might be only taken forward by big companies or consortiums; as it has been carried out in the case of the African oil palm. The decision to start breeding programs at the national level will depend on the costs of the program, and if it can be guaranteed its continuity in the time. For palm trees, due to the length of the growth cycle, it is necessary to obtain long term financings.

The example of the date palm owes its success to the international recognition of a fine product and of high quality, whose production has been based up to a short time ago on traditional varieties. As long as monocultures are started, and without the backup of strong breeding program, the date production is subject to the risks of genetic vulnerability.

Then it is considered that priority should be given to in situ management of wild populations of palm trees in the context of local development and the elaboration of high quality products.

\section{REFERENCES}

BARCELOS, E. et al. Genetic diversity and relationship in American and African oil palm as revealed by RFLP and AFLP molecular markers. Pesquisa Agropecuária Brasileira, v.37, n.8, p.11051114, 2002. Available from: <http://www.scielo.br/ scielo.php?pid=S0100-204X2002000800008\&script=sci_arttext $>$. 
Accessed: May, 04, 2011. doi: 10.1590/S0100204X2002000800008.

BILLOTTE, N. et al. Microsatellite-based high density linkage map in oil palm (Elaeis guineensis Jacq.). Theoretical Applied Genetics, v.110, p.754-765, 2005. Available fromc: <http:// www.springerlink.com/content/nvet1x0f5rjkgtgk/>. Acessed: May, 04, 2011. doi: 10.1007/s00122-004-1901-8.

COCHARD, B. et al. Geographic and genetic structure of African oil palm diversity suggests new approaches to breeding. Tree genetics \& genomes, v.5, p.493-504, 2009. Available from: <http://www.springerlink.com/content/069827156t0674q5/>. Acesso em: May, 04, 2011. doi: 10.1007/s11295-009-0203-3.

CLEMENT, C.R. et al. O potencial das palmeiras tropicais no Brasil: acertos e fracassos nas últimas décadas. Agrociencia, v.9, n.1-2, p.67-71, 2005. Available fromc: <http:// www.inpa.gov.br/cpca/charles/pdf/agrociencias_clementetal_2005.pdf>. Acessed: May, 04, 2011.

CORLEY, R.H.V.; TINKER, P.B. The oil palm. 5.ed. Oxford: Blackwell Science, 2003. 562p.

DRANSFIELD, J. et al. A new phylogenetic classification of the palm family, Arecaceae. Kew Bulletin, v.60, n.4, p.559569, 2005. Available from: <http://www.jstor.org/pss/ 25070242>. Accessed: May, 04, 2011.

EL HADRAMI, I.; EL HADRAMI, A. Breeding date palm. In: JAIN, S.M.; PRIYADARSHAN, P.M. Breeding plantation tree crops: tropical species. Berlin: Springer, 2009. Cap.6, p.191-216.

ELHOUMAIZI, M.A. et al. Phenotypic diversity of datepalm cultivars (Phoenix dactylifera L.) from Morocco. Genetic Resources and Crop Evolution, v.49, p.483-490, 2002. Available from: <http://www.springerlink.com/content/ qrx155w605p3x788/>. Accessed: May, 04, 2011. doi:10.1023/ A:1020968513494.

ELSHIBLI, S.; KORPELAINEN, H. Microsatellite markers reveal high genetic diversity in date palm (Phoenix dactylifera L.) germplasm from Sudan. Genetica, v.134, p.251-260, 2008. Available from: <http://www.springerlink.com/content/ 972224j2t083hu04/>. Accessed: May, 04, 2011. doi:10.1007/ s10709-007-9232-8.

FAO Statistics Division, 2010. Available from: <http:// faostat.fao.org/default.aspx>. Online. Accessed: Dez. 01, 2010.

HAYATI, A. et al. Genetic diversity of oil palm (Elaeis guineensis Jacq.) germplasm collections from África: implications for improvement and conservation of genetic resources. Theoretical and Applied Genetics, v.108, p.12741284, 2004. Available from: <http://www.springerlink.com/ content/lg1438b2jytmd1va/>. Accessed: May, 04, 2011. doi: 10.1007/s00122-003-1545-0.

HO, C-L. et al. Analysis and functional annotation of expressed sequence tags (ESTs) from multiple tissues of oil palm (Elaeis guineensis Jacq.). BMC Genomics, v.8, p.381, 2007. Available from: <http://www.biomedcentral.com/1471-2164-8-381>. Accessed: May, 04, 2011. doi: 10.1186/1471-2164-8-381.
ISA, Z.A. et al. PS12 breeding population for high oleic acid palm oil. MPOB, 2006. Information Series $\mathrm{N}^{\circ}$ 320, MPOB T.T $\mathrm{N}^{\circ}$ 313. ISSN 1511-7871. Available from: http://mpob.gov.my. Accessed: Jan. 30, 2010.

JALIGOT, E. et al. Somaclonal variation in oil palm (Elaeis guineensis Jacq.): the DNA methylation hypothesis. Plant Cell Reports, v.19, p.684-690, 2000. Available from: <http:/ /www.springerlink.com/content/5a7y21q5j92k2hjp/>. Accessed: May, 04, 2011. doi: 10.1007/s002999900177.

JONES, D.L. Palms throughout the world. Washington: Smithsonian Institution, 1995. 410p.

KUBIS, S.E. et al. Retroelements, transposons and methylation status in the genome of oil palm (Elaeis guineensis) and the relationship to somaclonal variation. Plant Molecular Biology, v.52, p.69-79, 2003. Available from: <http:// www.springerlink.com/content/k22x487768pj1561/>. Accessed: May, 04, 2011. doi: 10.1023/A:1023942309092.

MAIZURA, I. et al. Assessment of genetic diversity in oil palm (Elaeis guineensis Jacq.) using Restriction Fragment Length Polymorphism (RFLP). Genetic Resources and Crop Evolution, v.53, p.187-195, 2006. Available from: <http:// www.springerlink.com/content/f265865w2m40h219/>. Accessed: May, 04, 2011. doi: 10.1007/s10722-004-4004-0.

MAYES, S. et al. Molecular research in oil palm, the key oil crop for the future. In: MOORE, P.H. \& MING, R. Genomics of tropical crop plants. Berlin: Springer, 2008. Cap.15, p.371-404.

MOHD DIN, A. et al. PS11: High carotene E. guineensis breeding population. MPOB, 2006. Information Series n.319, MPOB T.T n.312. ISSN 1511-7871. Available from: <http:// mpob.gov.my>. Accessed: Jan. 30, 2010.

MOORE, H.; UHL, N. Major trends of evolution in Palm. Botanical Review, v.48, n.1, p.1-69, 1982. Available from: $<$ http://www.springerlink.com/content/t637574148146075/>. Accessed: May, 04, 2011. doi: 10.1007/BF02860535.

NASS, L.L. et al. Biofuels in Brazil: an overview. Crop Science, v.47, p.2228-2237, 2007. Available from: <https:// www.crops.org/publications/cs/tocs/47/6/2228>. Accessed: Set, 06, 2011. doi: 10.2135/cropsci2007.03.0166.

PURBA, A.R. et al. A new aspect of genetic diversity of Indonesian oil palm (Elaeis guineensis Jacq.) revealed by isoenzyme and AFLP markers and its consequences for breeding. Theoretical and Applied Genetic, v.101, p.956-961, 2000. Available from: <http://www.springerlink.com/content/ y3mp7n6w76gmcxd7/>. Accessed: May, 04, 2011. doi: $10.1007 / \mathrm{s} 001220051567$.

PURBA, A.R. et al. Prediction of oil palm (Elaeis guineensis Jacq) agronomic performances using the best linear unbiased predictor (BLUP). Theoretical and Applied Genetic, v.102, p.787-792, 2001. Available from: <http://www.springerlink.com/ content/u7dnkwn70ur3a7vj/>. Accessed: May, 04, 2011. doi: $10.1007 / \mathrm{s} 001220051711$.

REIS, M.S. et al. Management and conservation of natural populations in Atlantic Rain Forest: the case study of palm heart (Euterpe edulis Martius). Biotropica, v.32, n.4b, p.894-902, 
2000. Available from: <http://www.bioone.org/doi/abs/10.1646/ 0006-3606(2000)032\%5B0894:MACONP\%5D2.0.CO\%3B2>. Accessed: May, 04, 2011. doi: 10.1646/00063606(2000)032[0894:MACONP]2.0.CO;2.

REIS, M. S. et al. Palmito. Domesticação em paisagem natural. In: BARBIERI, R.L.; STUMPF, E.R.T. Origem e evolução de plantas cultivadas. Brasília: Embrapa Informação Tecnológica, 2008. p.651-676.

RIVAS, M. Desafíos y alternativas para la conservación in situ de los palmares de Butia capitata (Mart.) Becc. Agrociencia, v.9, n.1-2, p.161-168, 2005. Available from: <http:/ www.fagro.edu.uy/agrociencia/online.html>. Accessed: May, 04, 2011.

RHOUMA, S. et al. Genetic diversity and phylogenetic relationships in date-palms (Phoenix dactylifera L.) as assessed by random amplified microsatellite polymorphism markers (RAMPOs). Scientia Horticulturae, v.117, p.53-57, 2008. Available from: <http:// www.sciencedirect.com/science?_ob=ArticleURL\&_udi=B6TC34 S D N K D F - $2 \&$ \&_us e r $=7430124 \&$ \& cover Date $=06 \%$ 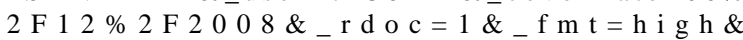 _orig=gateway\&_origin=gateway\&_sort=d\&_docan>. Accessed: May, 04, 2011. doi: 10.1016/j.scienta.2008.03.013.
SEDRA, M.H. et al. Identification and genetic diversity analysis of date palm (Phoenix dactylifera L.) varieties from Morocco using RAPD markers. Euphytica, v.103, p.75-82, 1998. Available from: <http://www.springerlink.com/content/ jrql362951805k24/>. Accessed: May, 04, 2011. doi: 10.1023/ A: 1018377827903

SWINGLE, W.T. Metaxenia in the date palm. Possibly a hormone action by the embryo or endosperm. Journal of Heredity, v.19, n.6, p.257-268, 1928. Available from: <http:/ /jhered.oxfordjournals.org/content/19/6/257.abstract $>$. Accessed: May, 04, 2011.

SOH, A.C. et al. Oil palm genetic improvement. Plant Breeding Reviews, v.22, p.165-219, 2003. Available from: $<$ ht t p://onlinelibrary.wiley.com/doi/ 10.1002 / 9780470650202.ch4/summary>. Accessed: May, 04, 2011. doi: 10.1002/9780470650202.ch4

WAHID, M.B. et al. Oil palm - achievements and potential. Plant Production Science, v.8, p.288-297, 2005. Available from: <http:/ / s c hol a r.google.com.br/s c hol ar ? h l = p t BR\& $q=O i l+p a l m+\% E 2 \% 80 \% 93+$ a chievements + and + potential\&btnG $=$ Pesquisar\&lr $=\& a s \_y l o=\& a s \_v i s=0>$. Accessed: May, 04, 2011. 